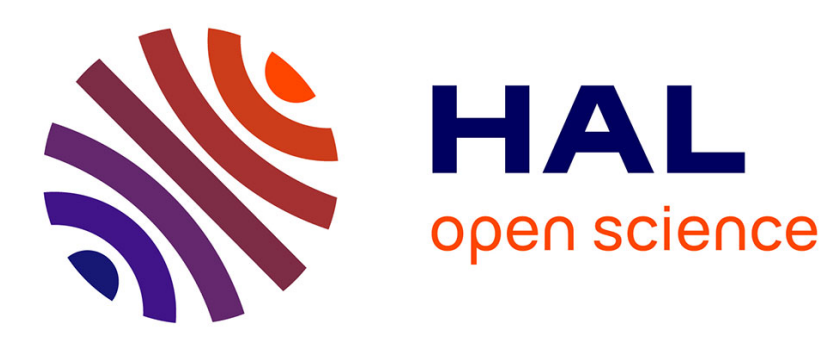

\title{
German Trade Unions and Right Extremism: Understanding Membership Attitudes
}

\author{
Michael Fichter
}

\section{To cite this version:}

Michael Fichter. German Trade Unions and Right Extremism: Understanding Membership Attitudes. European Journal of Industrial Relations, 2008, 14 (1), pp.65-84. 10.1177/0959680107086112 . hal00570973

\section{HAL Id: hal-00570973 https://hal.science/hal-00570973}

Submitted on 1 Mar 2011

HAL is a multi-disciplinary open access archive for the deposit and dissemination of scientific research documents, whether they are published or not. The documents may come from teaching and research institutions in France or abroad, or from public or private research centers.
L'archive ouverte pluridisciplinaire HAL, est destinée au dépôt et à la diffusion de documents scientifiques de niveau recherche, publiés ou non, émanant des établissements d'enseignement et de recherche français ou étrangers, des laboratoires publics ou privés. 


\title{
Michael Fichter
}

Freie Universität Berlin, Germany

\section{German Trade Unions and Right Extremism: Understanding Membership Attitudes}

\begin{abstract}
Right-wing populism and extremism present challenges for trade unions throughout Europe. This article reports findings from a representative survey and group interviews with union members in Germany. Far right attitudes are neither more nor less widespread among union members as a whole than in the population at large, but there are considerable differences within the membership. In particular, skilled workers as well as middle managers who are union members are significantly more inclined to extremist attitudes than non-unionists. The article discusses these results and presents several conclusions regarding future trade union policy.
\end{abstract}

KEYWORDS: political attitude - right extremism - trade union membership

\section{Introduction}

Within the EU, economic and monetary union, deregulation and cutbacks in welfare state protection, mass unemployment, workplace restructuring and relocation as well as the opening of previously protective borders - especially with the new member states - heavily affect the lives of the working population. As the European Commission noted in its 2006 report on industrial relations in Europe, governments and employers are arguing for widespread 'modernization', and increasing competition necessitates measures to enhance labour market flexibility and promote atypical forms of employment and work organization. Yet the Commission concludes (2006b: 16) that increasing labour market flexibility does not ... necessarily lead to higher job quality' and notes 'the potential risks of increased poverty and inequality in working conditions'. For its part, the ETUC (2006) argues that 'real wages, on average, are standing still and workers are no longer participating in the fruits of productivity increases. Many of them are being blackmailed into accepting pay cuts and working longer hours'. 
The resulting frustration and anxiety among workers can be evidenced in opinion polls. Eurobarometer surveys consistently place manual and non-manual workers among those who emphasize the negative aspects of globalization most strongly (EC, 2003) and who are most worried about unemployment (EC, 2005). By the end of 2005, an average of 40 percent of respondents in the EU-15 referred to relocation of production to countries with lower labour costs; with over 50 percent doing so in France, Germany, Greece and Belgium (EC, 2006a).

Right-wing extremist and populist movements throughout Europe have played on these fears, and over the past years have gained influence and governmental power in the Netherlands, Austria, Portugal, Italy, Norway and Denmark (Dörre, 2004). While 'accelerated modernization' (Betz, 1993: 420) is quite commonly regarded as a key contributing factor to this upsurge in right-wing political success, the assumption that support from those faced with deprivation and marginalization, the group of so-called 'modernization losers' (Klönne, 1989), was the basis of the renewed upsurge of the right, has been repeatedly questioned. Such a simplistic linking of socio-economic change and political behaviour neglects 'the dimension of political mediation and the subjective perception of the problems involved' (Minkenberg, 2000: 182). ${ }^{1}$

In this vein, recent research on socioeconomic change, individual reactions and the appeal of the extreme right in eight European countries ${ }^{2}$ has pointed to the need to examine this issue more deeply and to 'address the question as to how radical populism and right-wing extremism in Europe are linked with socio-economic change' (de Weerdt et al., 2004: 1). The researchers reject the simple explanation that modernization losers are the bedrock of the right; one of the archetypes of right-wing supporters is the 'threat to middle-class status and identity, insecurity through modernization; nostalgia and threat to cultural identity' (Hentges et al., 2003: 2).

\section{The Problems for Trade Unions}

In the face of membership decline, unemployment and job losses in traditional industries, along with corporate restructuring and job competition, trade unions are struggling to find ways of shoring up their bargaining positions and revitalizing their power to regulate and negotiate improvements in wages and working conditions. While attempting to develop strategies to organize and represent new constituencies, unions are challenged to uphold the gains and status of their traditional strongholds of membership in manufacturing as well. But focusing on the protection of hard-won achievements for the core membership can encourage nationalistic and xenophobic overtures, and discrimination against ethnic minorities (Wrench, 2004). 
Thus unions are confronted with the need to develop an understanding of the roots, forms and appeals of rightist politics and to devise strategies for combating the spread of right-wing support within their constituency.

While there is significant research on trade union policies toward racism and xenophobia in Europe (Wrench, 2004), as well as much survey data on popular attitudes (EUMC, 2005), less attention has been devoted to their interaction with possible additional factors to the prevalence of right-wing extremism in the working population. With its focus on how negative changes in working life have fostered sympathies among workers for the political appeal of the right, the SIREN research has contributed substantially to our understanding of this connection in a European context. Likewise, our own research with a focus on the particularities of the historical and political context in Germany has sought to determine the extent to which trade union members are prone to far right attitudes. German trade unions have unquestionably been at the political forefront in condemning all manifestations of right extremism, but until recently have been 'terra incognita' regarding the political attitudes on right-wing extremism within their own ranks.

Union membership and the existence of a 'trade union consciousness' were long considered to have an immunizing effect on such attitudes. Representative surveys in the 1960s and 1970s (Liepelt, 1967; Sinus, 1981) confirmed what many union leaders assumed, that 'union membership generally immunizes against National Socialism and Fascism' (Lutz, 1990: 291-2). However, as will be shown below, more recent research has argued that union members do not differ in their attitudes from non-members and are just as susceptible to right extremism (the 'mirror image' argument). Nevertheless, neither hypothesis has previously been convincingly tested empirically on a broadly representative sample of union members.

This article presents results from a two-year research project on trade union members in Germany and right extremism. ${ }^{3}$ The research was conducted between 2003 and 2005, a period of economic stagnation, downsizing, wage cuts and union membership losses (Fichter, 2005). It was based on a representative survey of members and non-members, supplemented by ten group interviews with nearly 60 union officials. Our original hypothesis was that the mirror image argument was invalid because union members have a definable 'trade union belief system': they become members because they hold particular beliefs and values associated with trade unionism. Yet under the threat of unemployment, workplace restructuring and job uncertainty, this consciousness would necessarily reflect contradictory attitudes and show potential cleavages. Thus we sought to find causes of right extremism peculiar to union members, and expected to find some members or groups of members to be relatively immune to right extremism, while others would prove more vulnerable. 


\section{The DGB and Right Extremism}

In his opening speech to the national congress in June 1998, the President of the Deutscher Gewerkschaftsbund (DGB, German Trade Union Confederation) declared that 'the DGB and its member unions will not tolerate anti-Semitism, racism or xenophobia. Indeed, everywhere and unrelentingly we will use every means at our disposal to combat such behaviour'. This reflected the degree to which union leaders perceived a growing need for a more vigorous defence of democratic values. Research on the electoral basis of the extreme right-wing party Die Republikaner (Roth, 1989; Stöss, 1990) along with studies of attitudes of young trade unionists (Held et al., 1996) had given notice to the unions that membership was not a reliable shield against extreme right attitudes. While the DGB was relieved that only 3.3 percent of the electorate actually voted for one of these right-wing parties in elections later that year, a more detailed statistical breakdown indicated that there was indeed a cause for alarm: 27 percent of all 18- to 24-year-old union members in eastern Germany had voted for such a party; and in western Germany the figure was 10 percent.

Such results led the DGB to create a high-level Commission on Right Extremism. Its report, published in 2000, concluded that opinions and attitudes of union members mirrored those of the non-union population. Since unions do not exist in a vacuum, it was not surprising that xenophobic and racist attitudes were just as virulent within the membership as in the general population.

For what reason should union members in particular be immune to the presentation of foreigners in the press as 'the problem'? And why should union members have faith in government pronouncements which claim that Germany is not a land of immigration, when such a denial is an obvious contradiction to their everyday experiences? (DGB, 2000).

Thus the report acknowledged the existence of right-wing attitudes among the members and it advanced some general explanations for this phenomenon, including the possibility that union acceptance of the argument that Germany must be more competitive (Standort Deutschland) played into the hands of the far right by providing arguments for the marginalization of foreigners. But in support of its 'mirror-image' conclusions regarding member attitudes, it had only limited empirical research to draw on and could thus offer little in the way of new insights.

\section{Research Design and Methodology}

The aim of our research was to fill this gap by establishing the extent of right extremism in the membership, its constituting factors, and how right extremism relates to other attitudes and beliefs which we expected 
to find among unionists. The survey was conducted in March and April 2003 and consisted of 4008 telephone interviews, each some 30 minutes in length. Our questionnaire was constructed with the dependent variable of far right attitudes (see below) and four independent variables of socio-political orientation (SPO), socio-economic status (SES), personality structure and fundamental political value orientations. The completed sample included 2006 union members and 2002 non-unionists, equally divided between western and eastern Germany. Over 90 percent of the unionists were members of a DGB union; the others belonged to smaller organizations such as the DBB (German Civil Service Confederation) or the CGB (Christian Trade Union Confederation).

In order to be compatible with the mainstream of research on right extremism in Germany and to promote comparativeness, we chose to use a definition of far right attitudes developed by a working party of social scientists recognized as the leading specialists in Germany in this field:

Right extremism is an attitude pattern which is constructed upon opinions of human inequality. These are expressed in the political sphere by an affinity to dictatorial forms of government, chauvinistic attitudes and the belittling of the harmfulness or even the justification of National Socialism. In the social sphere right extremism is characterized by anti-Semitism, xenophobism and social Darwinism. (Kreis, 2007: 12)

This definition was operationalized by formulating five statements for each of six different dimensions. Interviewees were asked to respond to these 30 statements on a scale of one to seven, with seven indicating complete agreement. Thus within each dimension, the scale of possible responses ranged from five $(5 \times 1)$ to $35(5 \times 7)$, with a mean value of 20 . Values of 21 and above were classed as indicating agreement with right extremism.

To illustrate the kind of statements used, one example is presented for each dimension:

Advocating an authoritarian dictatorship (Dimension 1) 'What Germany needs now is a single strong political party which represents the collective will of the people.'

Chawvinism (Dimension 2) 'The interests of our country need to be uncompromisingly and energetically represented in dealings with other countries.'

Xenophobia (Dimension 3) 'The large number of foreigners in the Federal Republic shows that we have been infiltrated to a dangerous degree.'

Anti-Semitism (Dimension 4) 'We have to defend ourselves against the way the Jews continually use the guilty conscience of the Germans.'

Social Darwinism (Dimension 5) 'There is worthy and worthless human existence.'

Trivialization of criticism of National Socialism (Dimension 6) 'National socialism had its good sides too.' 
Table 1 presents the percentage of those respondents whose scores indicated agreement on each dimension. This gives a first indication of the overall extent of both similarities and differences between members and non-members and between eastern and western respondents.

Following completion of the survey we conducted a series of groupbased qualitative interviews. Our intention was to have active trade unionists provide their views on the statistical results, in particular those attitudinal combinations which we found difficult to explain with quantitative methods. The quantitative findings gave us a 'directional thrust and set focal points' (Birsl et al., 1999: 97) for our qualitative research, which involved 10 group discussion interviews with trade union members. The 58 participants included nine women, seven migrants, 22 residents of eastern Germany and five retirees. Six of the eight DGB unions were represented. With the exception of the retirees, all of the participants were either salaried officials or held elected non-paid positions in a union or works council. Two researchers were present at each session to give thematic impulses and document the proceedings.

The seven themes, drawn from the survey findings, helped structure the discussions and presented the participants with a clear statement of the purpose of our research. The participants were asked to respond by discussing their own views and those of their colleagues. Following each two-hour session, we paraphrased the statements from the tapes and coded them according to a detailed list of topics relating to the following categories: right extremism, affinity to or rejection of right extremism, role and situation of the unions, union membership and non-members, economic changes and globalization, and politics in general.

TABLE 1. Agreement with Extreme Right-Wing Statements on Each Dimension (\%)

\begin{tabular}{lcccccccc}
\hline & \multicolumn{3}{c}{ Members } & & \multicolumn{3}{c}{ Non-members } & $\begin{array}{c}\text { All } \\
\text { respondents }\end{array}$ \\
& & & & & & & & \\
& All & West & East & & All & West & East & \\
\hline Dimension 1 & 18 & 17 & 26 & 20 & 16 & 33 & 19 \\
Dimension 2 & 31 & 31 & 30 & 32 & 31 & 36 & 32 \\
Dimension 3 & 23 & 20 & 36 & 26 & 23 & 40 & 26 \\
Dimension 4 & 23 & 24 & 19 & 22 & 22 & 24 & 23 \\
Dimension 5 & 12 & 11 & 16 & 13 & 12 & 20 & 13 \\
Dimension 6 & 28 & 29 & 24 & 29 & 29 & 28 & 29 \\
\hline
\end{tabular}




\section{Selected Findings}

The following summary focuses on those findings which are particularly important for the future of the German unions and their approaches to dealing with far right attitudes in their membership.

In regard to the union membership as a whole, our survey revealed only an insignificant difference in the percentage of far right attitudes between members (19.1) and non-members (20). At this level, the mirrorimage hypothesis advanced by the DGB Commission confirmed: as a whole, union members are no more (and no less) prone to far right attitudes than their non-member counterparts.

However, our findings reveal significant differences between and within relevant socio-economic groups. In western Germany (the pre-1990 Federal Republic) we found only a negligible statistical difference in far right attitudes between members (18.4 percent) and non-members (17.8 percent). In contrast, in eastern Germany (the former German Democratic Republic), the overall incidence of far right attitudes was significantly higher (27 percent), but we found that union members are relatively less susceptible (22.5 percent), while far right responses came from over 28 percent of the non-members.

\section{Socio-economic Status and Far Right Attitudes}

As can be seen in Table 2, labour force participants are generally far less susceptible to right extremism than non-participants. Second, unskilled and skilled workers and middle managers are more likely to entertain such attitudes if they are union members than if they are not: indeed nonskilled workers who are union members are almost twice as likely as non-members to have such attitudes (34 as against 18 percent). The same holds for organized middle managers (14 as against 7 percent). And

TABLE 2. Extreme Right Attitudes by Labour Force Status (\%)

\begin{tabular}{lcc}
\hline & Members & Non-members \\
\hline Labour force & & \\
$\quad$ participants & 17 & 12 \\
Non-active & 25 & 28 \\
Unemployed & 25 & 34 \\
Unskilled & 34 & 18 \\
Skilled & 20 & 18 \\
White-collar & 10 & 12 \\
Middle managers & 14 & 7 \\
\hline
\end{tabular}


skilled workers, who make up 25 percent of the union membership, are slightly more likely than their non-union counterparts to adopt such positions (20 as against 18 percent).

For the economically active respondents we constructed a three-strata model based on income and level of education. ${ }^{4}$ Our composite model combines rankings on the two dimensions as follows:

lower stratum: low + low, low + medium;

middle stratum: medium + medium, low + high;

upper stratum: medium + high, high + high .

Table 3 shows how the various job classifications and status groups are distributed across the strata. Interestingly, the lower stratum represents 44 percent of all respondents, but only about one-third of union members. Thirty-two percent of all respondents were from the middle stratum compared to nearly one half of the union members (45 percent). In the upper stratum the figures are 24 percent and 22 percent. From this it can be seen that the union membership is strongly concentrated in the middle stratum. Expressed in terms of labour force status groups, we find mostly skilled workers and middle or line managers among union members in the middle stratum.

How does socioeconomic status interact with union membership to influence the prevalence of far right attitudes? Among union members, those in the lower stratum have a significantly higher propensity towards right extremism than those in the middle and upper strata. However, when we compare union members and non-members within each of the three strata, we find that the lower stratum is obviously much more susceptible to right extremism, members (28 percent) somewhat less than nonmembers. This is consistent with findings on ethnic exclusionism in Europe (EUMC, 2005). In the upper stratum, we find a considerably lower incidence of far right attitudes. In this group, unionists are slightly less extremist in their attitudes (6 percent) than non-members (8 percent).

Of particular interest are the percentages of far right attitudes found in the middle stratum. Here, the proportion of extremist union members (19 percent) is in line with the overall incidence among trade unionists.

TABLE 3. Membership Groups and Non-members by Stratum (\%)

\begin{tabular}{lccccc}
\hline & Officials $^{\mathrm{a}}$ & $\begin{array}{c}\text { Active } \\
\text { members }\end{array}$ & $\begin{array}{c}\text { Passive } \\
\text { members }\end{array}$ & $\begin{array}{c}\text { All } \\
\text { members }\end{array}$ & $\begin{array}{c}\text { Non- } \\
\text { members }\end{array}$ \\
\hline Lower stratum & 20 & 30 & 35 & 33 & 46 \\
Middle stratum & 43 & 46 & 46 & 45 & 30 \\
Upper stratum & 37 & 24 & 19 & 22 & 24 \\
\hline
\end{tabular}

aBoth paid and lay union representatives. 
But non-members in this stratum are significantly less prone to agreeing to far right statements (13 percent).

\section{Socio-political Orientations and Far Right Attitudes}

Up to this point the findings as presented have been based on socioeconomic categories. And indeed, the literature on far right attitudes has often argued that increasing precariousness of social status and employment fosters the growth of such attitudes (Dörre, 2004). In contrast, however, other findings (Decker and Brähler, 2006; Heitmeyer, 2006) show that while socio-economic factors are certainly relevant, they provide only a partial and sometimes even an inconsistent and contradictory explanation for the endorsement of such views. Instead, the way in which individuals deal with their socio-economic situation, broadly labelled as socio-political orientations, has far-reaching explanatory relevance and significance. These orientations include personality traits such as authoritarianism or self-confidence, values, and general social and political viewpoints. In our evaluation of the survey data, two distinct and very broadly defined patterns of orientation emerged: one marked by democratic convictions and one dominated by authoritarian convictions. Again, while 'democratic' and 'authoritarian' include particular and distinct political views, they are used here in a much broader sense to refer to general socio-political orientations. We were able to show empirically that the stronger the former (democratic orientation), the less likely a person will harbour far right attitudes. Likewise, persons with authoritarian convictions have a clearly positive attitude toward right extremism, especially when such convictions are reinforced by 'gut reactions' of frustration and anxiety, triggering disaffection and disdain for the political process and the socio-economic and political system as a whole.

Referring again to our model of socio-economic strata, union members from all three strata have a stronger participatory orientation than nonmembers. From this we could assume that union members are more resistant to right extremism than non-members. However, a differentiation along socio-economic lines and a comparison with levels of disaffection and alienation from the political system shed a different light on this phenomenon.

Lower stratum: Here we find a comparatively low level of participatory orientations, an especially problematical social status and strong disaffection with the political system ('gut rejection' attitudes). However, union members with a participatory orientation of 13 percent are somewhat more democratically oriented and are less concerned about the precariousness of their social status than their non-union counterparts (10 percent).

Upper stratum: Attitudes in this category reflect relatively strong 'gut rejection' orientations. However, members are less prone to embrace far 
right attitudes than non-members because of their much stronger participatory values (45 as against 28 percent).

Middle stratum: The social status of members in this category is less endangered than that of non-members. And members have a stronger democratic and participatory orientation than non-members (25 as against 16 percent). However, their 'gut rejection' disposition is extremely strong. Union members are to a much greater extent than non-members highly dissatisfied with the political and socio-economic situation, they show a tendency to be indiscriminately critical, assuming a position of 'fundamental opposition'.

Again, it must be emphasized that support for far right positions cannot be measured solely on the basis of socio-economic status, nor do sociopolitical orientations alone provide a sufficient explanation of this phenomenon. Our findings have clearly shown, for example, that there is no deterministic relationship between the negative effects of socio-economic change (modernization losers) and the endorsement of far right positions. The problems associated with socio-economic change are a contributing factor, but certainly not capable of explaining right extremism in full. Together, however, socio-economic status and socio-political orientations form a powerful set of indicators from which we can draw insights regarding the context, the content and the distribution of far right attitudes among union members.

\section{Disaffection among Middle-Stratum Union Members}

In our model, the middle stratum includes 43 percent of all trade union officials and persons in this classification can not be generally categorized among the 'modernization losers'. And yet, one-half of all union members with far right attitudes are from this stratum. Stated differently, this group with far right attitudes comprises 10 percent of the whole membership. Since the difference between members and non-members in the upper and lower strata regarding such attitudes is relatively small, we focus on the middle stratum in search of reasons for union members being more vulnerable to right extremism than non-members from the same socio-economic group.

It is among members from the middle stratum that we found 'gut rejection' positions, a fundamental disaffection from the political system, to be especially virulent. Apparently, they stem from changes and uncertainties which these union members - in particular those in western Germany - perceive as already or potentially endangering their social status and achievements. The success story of the Federal Republic through to the 1980s was marked by the input and recognition achieved by union officials, active union members and works council members as the backbone of a successful integration of the working class and an 
income and labour policy of increasing affluence. Skilled industrial workers, a high percentage of who have long represented the core of union membership contributed strongly to the affluence of the Federal Republic, and they profited from the prosperity of the 'German model' (Markovits, 1982). Warnings of the status insecurity of this segment of the labour force (Herrigel, 1996) now seem to be more realistic in the face of globalization, labour market deregulation, wage dumping and losses of union power and workplace representation. This group is especially sensitive to the loss of union power and the dismantling of their own success story. Among these union members we found the greatest concentration of respondents with strong anxieties about losing their hard-won social status as employees and their recognized political status as union members.

Still, the question remains as to why a notable percentage of this group harbours far right sentiments in the face of such problems. A closer look at the insights we gained from the group discussions suggests additional explanations for this phenomenon.

\section{Far Right Sentiments from the Group Discussions}

While the survey turned up no evidence of the existence of a 'trade union belief system' in the membership, we did find that union officials and activists generally embraced a common understanding of 'unionism'. And this was confirmed by the group discussions. Among our participants we found that in particular, the principles of equality, solidarity, internationalism as well as codetermination and participation clearly can be designated as 'immunizers' against right extremism as long as such beliefs are steadfast and reliable interpreters of reality. However, the increasing economic and political challenges facing unions have weakened their capacity to fulfil their proclaimed role and goals. The response of a considerable number of members is disappointment and frustration, which can express itself in a variety of ways, including resigning from membership, a lowering of expectations (concession bargaining), or in demands that 'the union' protest adverse policies more vehemently, or even in a willingness to entertain the simple solutions of the far right (a stronger state, a strong leader). As such, it is not the principles of the 'belief system' themselves which open the door for far right attitudes; rather it is their negation and the feeling of individual and collective powerlessness in the context of developments which erode the achievements of the 'German model'. The union 'belief system' is open to far right attitudes because its programmatic assurances of protection and collective solidarity seem hollow when challenged by employers and by politically instrumented changes to the system. Three examples from the group discussions will help illustrate this. 


\section{Wage Dumping and 'Black Market' Competition}

'Foreigners' and the prevalence of xenophobia are an omnipresent issue in the world of work in Germany, and the group discussions reflected this quite clearly. Although the German unions have taken a clear stand against scapegoating foreigners, ${ }^{5}$ the increasing competition for jobs as firms downsize or relocate production outside Germany together with the opening of the German labour market within the EU has heightened aggression against foreigners and such statements as 'the foreigners are stealing our jobs' have become commonplace in certain sectors of the economy such as construction and services.

I know that this is a delicate topic in the construction union [IG BAU], for example, in Cottbus [on the Polish border]; it is virtually impossible to hold a reasonable discussion on this topic because the membership is so adamant about their position: the foreigners are stealing our jobs!

Others in the discussion pointed out that this is certainly not the official position of the union, and that the presence of foreign workers in Germany is not the cause of the economic problems. Most of the participants from private enterprises pointed out that the workforce where they were employed was multinational. At work, they could vouch for the fact that there was no inherent sign of xenophobia. All nationalities Germans and foreigners who live in Germany with extended work permits - cooperated well together:

I have worked in the mine since 1971, together with Turks, Italians, French, Spaniards, Swiss - you name it, from every country around us. And I never felt that any of them was taking anything away from us, any particular job or employment in general. Everyone, independent of their nationality, who lives in Germany, could apply for the job and get it.

On the other hand, some of the discussants pointed out that when job cuts were announced, or a particular department was scheduled to be outsourced, 'foreigners' became an issue which divided the workforce. As reported by our participants, some of whom became quite emotional while discussing the problem, the restlessness and uncertainty was even greater when jobs were to be relocated to a foreign country. And there was a general current of feeling unjustly treated and at a disadvantage when it was necessary to compete with foreigners working but not living in Germany. Here is an example, in this case from a worker who had immigrated from Poland years before.

We Germans, we live here and pay our rent and our taxes. And when my brother comes here from Poland, where he lives with his family, he works here for two months, lives with me, makes money and lowers the market price with his $€ 5$ or 6 an hour. Then he goes back home with his earnings, 
stays for a month and then comes back again. And that's why I don't want him working here.

Another discussant had this to say:

A construction site in Dortmund, the Holzmann Co. has hired 300

Romanians for $€ 3$ an hour. The union knows that, and the mayor knows that. They're ruining the market, and who's to blame? It's the politicians at the top.

The dilemma for these unionists is evident: how can the high level of union wage standards and working conditions be protected? Combating non-regulated work and wage dumping is their obvious answer, but this puts the union in a potentially anti-foreigner position since this kind of work is usually done by foreign workers. For the German construction workers union (IG BAU) the issue is the protection of standards from any undercutting, regardless of the nationality or ethnic background of the perpetrator. The union has rejected the notion of priority treatment for Germans in favour of protecting persons in the labour force living in Germany. But this is an argument which is not readily shared by all, and union activities to report wage dumping in cooperation with public authorities have been roundly criticized by anti-racist and foreigner support groups. But it seems to have the full support of union officials and many members. Nevertheless, some unionists were fully aware that union arguments for organizing solidarity to protect nationally achieved labour standards were being undermined by globalization and labour migration, opening the way for the spread of xenophobic and far right attitudes.

\section{The Loss of Security, Solidarity and Social Status}

In their struggle for better wages and working conditions and in their demands for worker participation, unions awaken expectations. In times of crisis or restructuring, those expectations may even grow, although unions are often less able to fulfill them. Disappointment and a feeling of helplessness may spread:

Unemployment, the growing power of companies just from one day to the next to say 'Pack your belongings; we're closing down this plant.' Why is that possible? Where does that leave me? My existence is threatened! This is the kind of feeling that many have. Even those with secure jobs feel that they could be the next in line.

Competition is growing - fewer jobs, more competition.

In the group discussions there was a broad consensus that conditions were generally worse today than in former times and that they were worsening. While the conclusions drawn from that attitude covered a 
wide range of positions, our findings suggest that some of the disappointed members look for the fulfilment of their expectations in far right arguments and solutions. 'Politics' in general, that is, the political establishment - and in particular social democracy (SPD) - is blamed for the worsening situation of working people and for not upholding the principles of social justice: "We have a "red" government which is ignorant regarding basic social policy'. Repeatedly, we heard the argument that the demise of the SPD as the political arm of the labour movement defending social rights, and the failure of the unions and their supporters to mount an effective opposition, had led to political disaster, resulting in a growing 'wish for a strong hand to bring an end to the chaos'. Dissatisfaction with the outcomes from the political process is transformed into dissatisfaction with the processes themselves. Politics is not only socially unjust, it is also chaos under the label of democracy. Arguments such as these which result from disappointment link social justice to 'order', which can only be restored via authoritarian means. When democratic participation is dysfunctional because it is incomplete, and when political alternatives are unavailable in the party system, ${ }^{6}$ then only a 'strong hand' would be capable of restoring order and ensuring social justice.

Such utterances reveal that social justice, one of the principles of a union belief system, can provide an opening for far right attitudes in the guise of an authoritarian state, when both the government and the unions fail to meet the expectations of union members in protecting jobs, providing socio-political correctives to the dynamics of capitalism and guaranteeing a measure of social security. Among union members we found such attitudes expressed in terms of the spread of existential fears and the disappearance of any hope for collective interest representation and organized solidarity.

People have recognized who really runs things in this country, it's the employers who are in charge, not the politicians. The employers can do what they want. Whether they operate in this country or move their plants to somewhere else, that's not their worry. And that's why people long for the strong man who will tell the employers what they're supposed to do.

People are not well off, and everyone blames someone else, while hoping that someone will come along and solve their problems.

What is especially notable about these kinds of attitudes is that they are not only found among so-called modernization losers or the downwardly mobile, a finding which the SIREN project also confirmed (Flecker and Hentges, 2004). Even our discussants from Volkswagen, the epitome of a social partnership employer, expressed deep-felt uncertainty over the future of their jobs. The core of union membership, the better paid skilled workers from large industrial plants, is no longer particularly resistant to far right interpretations of the current situation. 


\section{Politically Active Trade Unionism}

A belief in politically active unionism, incorporating the idea of the union as a community of common values, is not shared extensively in the membership, even among those generally supportive of the other elements of a union belief system. Two different positions showed up in the group discussions. When the participants were asked to comment on our overall finding that union members are just as prone to far right attitudes as non-members, some reacted with surprise and disbelief; others saw nothing unusual in this result.

The latter group regarded unions as having the purely economic function of reducing competition among workers in the labour market. Joining a union for this reason would not be dependent on a person's political persuasion or on the union's political programme. In contrast, those who understood union membership to reflect a workers' movement mentality and a common political value orientation (in essence, leftist), were shocked by our finding.

Moreover, among the supporters of politically active unionism were persons with what we call a 'traditional socialist' attitude pattern: support for nationalizing large corporations, for the continuing importance of class conflict between the 'haves' and 'have-nots', and for the belief that there can be no real democracy in capitalism. Perhaps surprisingly to some, we found that such an attitude pattern did not necessarily immunize against far right attitudes but could correlate positively with them.

In the group discussions we found that especially the younger unionists randomly selected individual phenomena when referring to common historical traits between leftist and rightist movements. In reference to classic totalitarianism one of the participants said that both the left and the right had the orientation to a 'strong man' and a 'strong state' in common. And nationalization of key enterprises, several argued, seemed to fit well to rightist demands that the government protect jobs for Germans.

From an historical perspective, right extremist, fascist and national 'socialist' movements were able to use elements of Marxist social critique for their own purposes. And the experience of a Soviet-style dictatorship in East Germany has heightened the impression of similarity for many, especially because after 1989 the theoretical tradition of democratichumanitarian socialism has been unable to present a convincing political alternative. Instead, the far right has used elements of leftist political demands such as the protection and maintenance of the welfare state to join the protests against labour market reforms pursued by both the Schröder coalition (SPD-Green Party, 1998-2005) and the current SPDCDU coalition. 


\section{Recommendations for Trade Union Policy}

How might unions - not only in Germany - respond to the prevalence of far right attitudes among the membership? An important finding from our research is that factors of socio-economic status alone cannot explain the incidence and distribution of such attitudes. There is a clear indication that democratic convictions (strong political consciousness and selfconfidence, democratic orientations, libertarian positions) have a noticeably positive impact on preventing the spread of far right attitudes. As such, it seems imperative that unions develop a strategic response to right extremism which can build on this insight.

Far right attitudes among union members are a reflection of their understanding of extensive socio-economic changes and of the crisis in which trade unions currently find themselves. Right extremists are moving to the fore with their own arguments, while union arguments are apparently not reaching a sizeable portion of the membership. If unions do not effectively contest the conventional wisdom that 'there is no alternative' to insecurity and job losses because of the pressures of competitiveness, members are likely to be susceptible to far right positions. Their frustrations and anxieties are understandable, and right extremism has an appeal as a functional means of dealing with problems at work. If a solidaristic and democratic handling of problems and conflicts is to be achieved, a union strategy needs to be devised which builds on understanding and handling the fears and anxieties raised by threats of unemployment, outsourcing and wage undercutting. The way in which these and other political and socio-economic issues such as globalization and relocation are analysed, interpreted, and put in a differentiated context of union strategy will determine the ability of the unions to prevent the spread of far right attitudes among the members.

Over the past years, the DGB and its member unions have launched a wide range of activities including involvement in European networks, demonstrations, campaigns, educational projects and workplace agreements designed to combat xenophobia and right extremism - but not as a particular problem of their own membership. To address this issue specifically, we regard the following insights from our research as essential ingredients for developing a successful union strategy:

Trade unions need to represent a clear set of values, such as social justice and democracy, for which they are willing to fight, if they want to succeed in combating far right attitudes in their membership. Posturing merely as a labour market cartel or as an organization to service its members as customers is insufficient. 'The struggle for trade union organization is thus a struggle for the hearts and minds of people; in other words, a battle of ideas.' (Hyman, 1999: 4)

Trade unionism which embraces a 'community of values' is also destined to encourage and enable participation in the organization. This is 
not only an issue for union educational departments. For some German union officials, caught in a web of organizational demands, promoting participation either leads to chaos or is too time-consuming (a passive membership is easier to handle). But in our study, characteristics such as initiative and participation appeared as especially effective inhibitors of right extremism. Members who have a chance at their workplace or in the union to make a difference or to contribute to achieving a common goal generally reject far right positions. Only strong individuals are capable of solidarity and only solidaristic individuals are strong.

Because the readiness on the part of union members to embrace right extreme positions results from their fears and anxieties about their future livelihood, a trade union strategy for combating right extremism belongs in the mainstream of union policy and activities. German unions could learn from the positive experiences of British trade unions in addressing racism through proactive policies (Wrench, 2004).

Our study showed that there is a definite affinity between authoritarian character traits, rigid thinking and far right attitudes. Rigidity is the readiness to seek 'simple' solutions to complex problems and issues, and to think in terms of accepting developments as being unavoidable necessities and the impossibility of alternatives. Unions need to show the way to more differentiated approaches and individual capacity for judgement.

Finally, far right and right-wing populist movements and organizations exist in many other EU member states as well as Germany. As research on trade union policies toward the challenges of cross-border labour migration and the relocation of jobs in other EU member states has shown, responses may vary over time, depending on the particular local and national context (Martens, 1999; Penninx and Roosblad, 2000; Wrench, 2004). But in the light of the Europeanization of the market and the importance of strengthening democratic institutions in the EU as well as furthering the development of European-wide regulations for decent working conditions, there is a growing need for increased cross-border cooperation and the exchange of ideas by unions, both in combating the sources of right extremism and in furthering a democratic political culture in Europe.

Above all, the goal of counteracting right extremism should be to expose such a position as a helpless flight from responsibility, reflective judgment and freedom, while at the same time promoting collective, solidaristic and democratic involvement as the better alternative. The challenge will be to mobilize trade union members with their generally strong democratic and participatory traits on behalf of this endeavour.

\section{ACKNOWLEDGEMENT}

The author and his project collaborators Joachim Kreis, Richard Stöss and Bodo Zeuner thank the Hans-Böckler-Stiftung and the Otto-Brenner-Stiftung for their financial support for the research on which this article is based. 


\section{NOTES}

1 See also Betz (1993: 421), who argues that the political ambiguities of rightwing programmes are the result of an attempt to forge 'an alliance between losers and winners of the present acceleration of the modernization process'.

2 See EU research project SIREN (Socio-Economic Change, Individual Reactions and the Appeal of the Extreme Right) [http://www.siren.at/en].

3 The final report, authored by M. Fichter, J. Kreis, R. Stöss and B. Zeuner, is available in German at [http://www.polwiss.fu-berlin.de/projekte/gewrex/ gewrex_anfang.htm].

4 The classification criteria are: monthly personal net income of under $€ 800$, $€ 800$ to $€ 1499$, and $€ 1500$ and above; and low, medium or high level of general education.

5 Though the DGB backed the German government's restrictions on the free movement of labour from the 10 new member states in central and eastern Europe in 2004.

6 The project survey and group interviews were completed before a new leftist political party Wablalternative für Sozialgerechtigkeit (WASG) was founded. In the Federal elections of 2005, the WASG achieved notable support in areas in which the right extreme parties had been expected to do well.

\section{REFERENCES}

Betz, H.-G. (1993) 'The New Politics of Resentment: Radical Right-Wing Populist Parties in Western Europe', Comparative Politics 25(4): 413-27. Birsl, U., Ottens, S. and Sturhan, K. (1999) Männlich - weiblich, türkisch deutsch: Lebensverbältnisse und Orientierungen von Industriebeschäftigten. Opladen: Leske + Budrich

De Weerdt, Y., De Witte, H., Catellani, P. and Milesi, P. (2004) Turning Right? Socio-economic Change and the Receptiveness of European Workers to the Extreme Right. Report on the survey Analysis and Results, Deliverable 4 for the project 'Socio-Economic Change, Individual Reactions and the Appeal of the Extreme Right' (SIREN). Vienna: Ringelnik GmbH.

Decker, O. and Brähler, E. (2006) Vom Rand zur Mitte. Rechtsextreme Einstellungen und ibre Einflussfaktoren in Deutschland. Bonn: FriedrichEbert-Stiftung.

Deutscher Gewerkschaftsbund (DGB) - Bundesvorstand (2000) 'Schlussbericht der Kommission Rechtsextremismus', Red. Dieter Pougin, Berlin

Dörre, K. (2004) 'Rechte Orientierungen unter Lohnabhängigen. Ursachen, Auswirkungen, Gegenstrategien', in J. Beerhorst, A. Demirovic and M. Guggemos (eds) Kritische Theorie im gesellschaftlichen Strukturwandel, pp. 289-317. Frankfurt/M: edition suhrkamp.

EC (European Commission) (2003) Flash Eurobarometer 1516. Globalisation. Brussels: EC.

EC (2005) Eurobarometer 63. Public Opinion in the European Union. Brussels: EC.

EC (2006a) Eurobarometer 64. Public Opinion in the European Union. Brussels: EC. 
EC (2006b) Industrial Relations in Europe 2006. Luxembourg: Office for Official Publications of the European Communities.

EUMC (European Monitoring Centre on Racism and Xenophobia) (2005) Majorities' Attitudes towards Minorities: Key Findings from the Eurobarometer and the European Social Survey. Summary. Vienna: Manz Crossmedia ETUC (2006) 'Move Social Europe Up a Gear!', Resolution of the Executive Committee, Brussels, 14-15 March, available online at: [http://www.etuc.org/ a/2209].

Fichter, M. (2005) 'The German Way. Still Treading the Path of Institutionalized Labor Relations?', in S. Beck, F. Klobes and C. Scherrer (eds) Surviving Globalization? Perspectives for the German Economic Model, pp. 93-110. Dordrecht: Springer.

Flecker, J. and Hentges, G. (2004) 'Rechtspopulistische Konjunkturen in Europa - sozioökonomischer Wandel und politische Orientierungen', in J. Bischoff, K. Dörre and E. Gauthier (eds) Moderner Rechtspopulismus. Ursachen, Wirkungen, Gegenstrategien, pp. 119-49. Hamburg: VSA-Verlag. Held, J., Horn, H.-W. and Marvakis, A. (1996) Gespaltene Jugend. Politische Orientierungen jugendlicher ArbeitnehmerInnen. Opladen: Leske + Budrich. Heitmeyer, W. (2006) 'Wo sich Angst breit macht', Die Zeit 51, 14 December, p. 21. Hentges, G., Meyer, M.-H., Flecker, J., Kirschenhofer, S., Thoft, E., Grinderslev, E. and Balazs, G. (2003) The Abandoned Worker: Socio-economic Change and the Attraction of Right-wing Populism: European Synthesis Report on Qualitative Findings, 'Socio-Economic Change, Individual Reactions and the Appeal of the Extreme Right' (SIREN) 3. Vienna: Ringelnik.

Herrigel, G. (1996) Industrial Constructions: The Sources of German Industrial Power. Cambridge: Cambridge University Press.

Hyman, R. (1999) 'An Emerging Agenda for Trade Unions?', discussion paper DP/98/1999, IILS, Geneva.

Klönne, A. (1989) 'Aufstand der Modernisierungsopfer', Blätter für deutsche und internationale Politik 34(5): 545-8.

Kreis, J. (2007) 'Zur Messung von rechtsextremer Einstellung: Probleme und Kontroversen am Beispiel zweier Studien', Arbeitshefte aus dem OttoStammer-Zentrum Nr. 12, Berlin, available online at: [http://www.polwiss. fu-berlin.de/osz/index.htm].

Liepelt, K. (1967) 'Anhänger der neuen Rechtspartei. Ein Beitrag zur Diskussion über das Wählerreservoir der NPD’, Politische Vierteljabresschrift 8(1): 237-71.

Lutz, H. (1990) 'Gewerkschaftliche Auseinandersetzung mit dem Rechtsextremismus am Beispiel der Gewerkschaft der Polizei', in K. Bodewig, R. Hesels and D. Mahlberg (eds) Die schleichende Gefahr. Rechtsextremismus beute, pp. 290-300. Essen: Klartext.

Markovits, A. (ed.) (1982) The Political Economy of West Germany: Model Germany. New York: Praeger.

Martens, A. (1999) 'Migratory Movements, the Position, the Outlook: Charting Theory and Practice for Trade Unions', in J. Wrench, A. Rea and N. Ouali (eds) Migrants, Ethnic Minorities and the Labour Market: Integration and Exclusion in Europe, pp. 219-28. London: Macmillan.

Minkenberg, M. (2000) 'The Renewal of the Radical Right: Between Modernity and Anti-modernity', Government and Opposition 35(2): 170-88. 
Penninx, R. and Roosblad, J. (eds) (2000) Trade Unions, Immigration, and Immigrants in Europe 1960-1993. Oxford: Berghahn.

Roth, D. (1989) 'Sind die Republikaner die fünfte Partei?', Aus Politik und Zeitgeschichte B41-2: 10-20.

Sinus (1981) 5 Millionen Deutsche: 'Wir sollten wieder einen Fübrer haben ...'. Die SINUS-Studie über rechtsextremistische Einstellungen bei den Deutschen, Reinbek: Rowohlt Taschenbuch Verlag.

Stöss, R. (1990) Die Republikaner. Woher sie kommen - Was sie wollen - Wer sie wäblt - Was zu tun ist, 2nd edn, Cologne: Bund-Verlag.

Wrench, J. (2004) 'Trade Union Responses to Immigrants and Ethnic Inequality in Denmark and the UK: The Context of Consensus and Conflict', European Journal of Industrial Relations 10(1): 7-30.

MICHAEL FICHTER is a senior researcher and lecturer in the Department of Political Science (Otto-Suhr-Institut) at the Freie Universität Berlin. ADDRESS: Otto-Suhr-Institut, FU Berlin, Innestraße 26, 14195 Berlin, Germany. [e-mail: michael.fichter@fu-berlin.de] 